\title{
Three New Stereoisomers of Condensed Tannins from the Roots of Rosa multiflora
}

\author{
Kwan Hee PArk, Sung Kyu Kim, Sun Eun Chol, Joo Hee Kwon, Myung Hwan OH, and \\ Min Won LeE*
}

Department of Pharmacognosy, College of Pharmacy, Chung-Ang University; Seoul 156-756, Republic of Korea.

Received March 8, 2010; accepted June 28, 2010; published online June 29, 2010

\begin{abstract}
Three new stereoisomers of condensed tannins (1-3), and four known phenolic compounds (4-7) were isolated from the $80 \%$ acetone extract of the roots of Rosa multiflora Thunberg. The structures of these compounds were elucidated using 1D/2D NMR, high resolution (HR)-MS, and circular dichroism (CD) spectra. In order to evaluate their anti-oxidative and anti-inflammatory activities, their 1,1-diphenyl-2-picrylhydrazyl (DPPH) radical scavenging activity and inhibitory activity on nitric oxide (NO) production were determined.
\end{abstract}

Key words Rosa multiflora; condensed tannin; proguibourtinidin; profisetinidin; phlobatannin

Rosa multiflora Thunberg (RM), also known as the Multiflora Rose, the Baby Rose, or the Rambler Rose, is native to China, Japan, and Korea. RM was first introduced in the West in 1866 as a rootstock for ornamental roses and has been sometimes been viewed as a weed because of its tenacious nature and prolific growth characteristics. ${ }^{1)}$ However, all parts of RM, that is, hips, leaves, stems, flowers, and roots, have been used as folk medicines in Korea. In particular, the roots of RM, the plant material utilized in this study, have traditionally been used to treat hemorrhage and rheumatism. ${ }^{2)}$ Recently, some lignans and triterpenes were isolated from these roots. ${ }^{3-6)}$ In the present study, we describe the isolation and elucidation of the three new structural isomers of condensed tannins that are related to proanthocyanidins (proguibourtinidin, profisetinidin and phlobatannin) and possess unique absolute configurations. In addition, their antioxidative and anti-inflammatory activities are evaluated.

\section{Results and Discussion}

The $80 \%$ acetone extract of the roots of RM was subjected to repeated liquid column chromatography using Sephadex LH-20, MCI-gel CHP20P and reversed phase medium pressure liquid chromatography (MPLC) to afford seven compounds including 3 new condensed tannins (Fig. 1). The known compounds (4-7) were identified as gallic acid, cat chin, gallocatechin and procyanidin B-3, respectively by comparing their spectroscopic (MS and NMR) data with literature values. ${ }^{7,8)}$

Compound 1 was obtained as an amorphous red-brown powder. High resolution (HR)-negative FAB-MS $(\mathrm{m} / \mathrm{z}$ $545.1453[\mathrm{M}-\mathrm{H}]^{-}$, Calcd for $\left.\mathrm{C}_{30} \mathrm{H}_{25} \mathrm{O}_{10}, 545.1448\right)$ indicated its molecular formula was $\mathrm{C}_{30} \mathrm{H}_{26} \mathrm{O}_{10}$. The FT-IR spectrum of 1 exhibited vibration bands corresponding to free hydroxyl $\left(3350 \mathrm{~cm}^{-1}\right)$, aliphatic $\left(2920 \mathrm{~cm}^{-1}\right)$ and aromatic $\left(1475 \mathrm{~cm}^{-1}\right)$ components. During thin layer chromatography (TLC), 1 was detected using the UV lamp at $254 \mathrm{~nm}$, as a dark green spot by spraying with $\mathrm{FeCl}_{3}$ solution, or as an orange spot by spraying with anisaldehyde- $\mathrm{H}_{2} \mathrm{SO}_{4}$ solution and heating. ${ }^{1} \mathrm{H}-\mathrm{NMR}$ showed the typical proton signals of flavan-3-ol, aromatic signals at $6.0-7.0 \mathrm{ppm}$, and aliphatic signals at $2.4-4.6 \mathrm{ppm} .{ }^{1} \mathrm{H}-$ and ${ }^{13} \mathrm{C}-\mathrm{NMR}$ spectra contained signals indicating a rotational conformer. ${ }^{9)}$ All the above data suggested that compound $\mathbf{1}$ was a proanthocyanidin (Table 1).
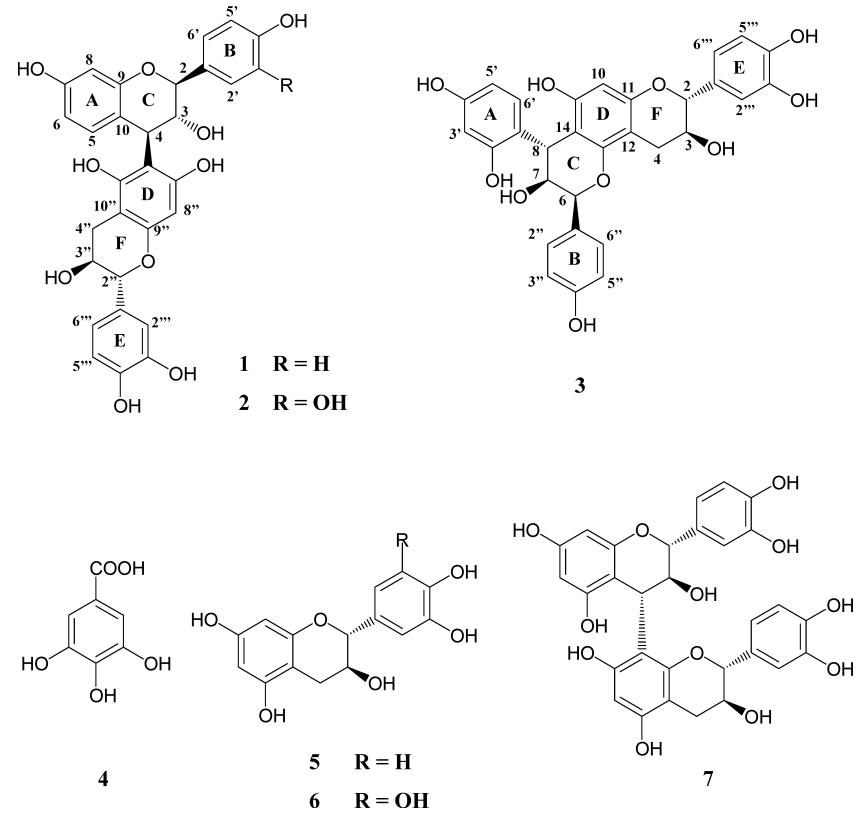

Fig. 1. Structures of Compounds $1-7$

Careful analysis of the ${ }^{1} \mathrm{H}-\mathrm{NMR}$ spectrum of compound $\mathbf{1}$ showed an aromatic ABX-spin system $\left[\delta_{\mathrm{H}} 6.48(1 \mathrm{H}, \mathrm{d}, J=\right.$ $9.0 \mathrm{~Hz}, \mathrm{H}-5), 6.17(1 \mathrm{H}, \mathrm{dd}, J=2.4,9.0 \mathrm{~Hz}, \mathrm{H}-6)$ and 6.07 $(1 \mathrm{H}, \mathrm{d}, J=2.4 \mathrm{~Hz}, \mathrm{H}-8)]$ and an aromatic $\mathrm{A}_{2} \mathrm{~B}_{2}$-spin system $\left[\delta_{\mathrm{H}} 7.17\left(2 \mathrm{H}, \mathrm{d}, J=8.4 \mathrm{~Hz}, \mathrm{H}-2^{\prime}, \mathrm{H}-6^{\prime}\right)\right.$ and $6.72(2 \mathrm{H}, \mathrm{d}, J=$ $\left.\left.8.4 \mathrm{~Hz}, \mathrm{H}-3^{\prime}, \mathrm{H}-5^{\prime}\right)\right]$ (Table 1). The aliphatic group was assigned to three correlated methines $\left[\delta_{\mathrm{H}} 4.34(1 \mathrm{H}, \mathrm{d}, J=9.3\right.$ $\mathrm{Hz}, \mathrm{H}-4) \leftrightarrow 4.48(1 \mathrm{H}, \mathrm{t}, J=9.3 \mathrm{~Hz}, \mathrm{H}-3) \leftrightarrow 4.44(1 \mathrm{H}, \mathrm{d}, J=9.3$ $\mathrm{Hz}, \mathrm{H}-2)]$ by correlation spectroscopy (COSY), and their carbon signals were assigned to $\delta_{\mathrm{C}} 83.1(\mathrm{C}-2), 68.2(\mathrm{C}-3)$ and 40.7 (C-4) by heteronuclear single quantum coherence (HSQC) (Fig. 2, Table 1). These findings suggested a guibourtinidol moiety.

Another aromatic ABX-spin system $\left[\delta_{\mathrm{H}} 6.75(1 \mathrm{H}, \mathrm{d}, J=\right.$ $\left.1.8 \mathrm{~Hz}, \mathrm{H}-2^{\prime \prime \prime}\right), 6.67\left(1 \mathrm{H}, \mathrm{d}, J=8.4 \mathrm{~Hz}, \mathrm{H}-5^{\prime \prime \prime}\right)$ and $6.63(1 \mathrm{H}$, dd, $\left.\left.J=1.8,8.4 \mathrm{~Hz}, \mathrm{H}-6^{\prime \prime \prime}\right)\right]$ and an additional aromatic singlet signal $\left[\delta_{\mathrm{H}} 5.90\left(1 \mathrm{H}, \mathrm{s}, \mathrm{H}-6^{\prime \prime}\right.\right.$ or $\left.\left.8^{\prime \prime}\right)\right]$ were observed in the ${ }^{1} \mathrm{H}-$ NMR spectrum of $\mathbf{1}$ (Table 1). Another aliphatic chain was assigned to a methylene $\left[\delta_{\mathrm{H}} 2.80(1 \mathrm{H}, \mathrm{dd}, J=5.4,15.9 \mathrm{~Hz}\right.$, $\left.\mathrm{H}-4_{\mathrm{eq}}{ }^{\prime \prime}\right)$ and $\left.2.41\left(1 \mathrm{H}, \mathrm{dd}, J=8.4,15.9 \mathrm{~Hz}, \mathrm{H}-4_{\mathrm{ax}}{ }^{\prime \prime}\right)\right]$ and two 
methines $\left[\delta_{\mathrm{H}} 4.51\left(1 \mathrm{H}, \mathrm{d}, J=7.8 \mathrm{~Hz}, \mathrm{H}-2^{\prime \prime}\right)\right.$ and $3.77(1 \mathrm{H}$, ddd, $\left.\left.J=5.4,7.8,8.4 \mathrm{~Hz}, \mathrm{H}-3^{\prime \prime}\right)\right]$ by COSY, and their carbon signals were assigned as $\delta_{\mathrm{C}} 81.6\left(\mathrm{C}-2^{\prime \prime}\right), 67.1$ (C-3") and 28.9 (C-4") by HSQC (Fig. 2). These findings suggested the presence of a catechin moiety.

The proton signal, $\delta_{\mathrm{H}} 4.34$ of $\mathrm{H}-4$ on the guibourtinidol moiety (upper unit), showed correlations with some carbon signals on the catechin moiety (lower unit), that is, $\delta_{\mathrm{C}} 154.5$, 154.1 and 106.7 by heteronuclear multiple bond coherence (HMBC). Of these carbon signals, $\delta_{\mathrm{C}} 106.7$ represents a connecting point of the lower unit and may be due to $\mathrm{C}-6$ " or $\mathrm{C}$ $8^{\prime \prime}$ (D-ring). Based on the HMBC, the correlations between additional prominent aromatic singlet signal at $\delta_{\mathrm{H}} 5.90, \delta_{\mathrm{H}}$ $4.51\left(\mathrm{H}-2^{\prime \prime}\right.$ as confirmed by COSY) and $\delta_{\mathrm{C}} 155.6$ (oxygen
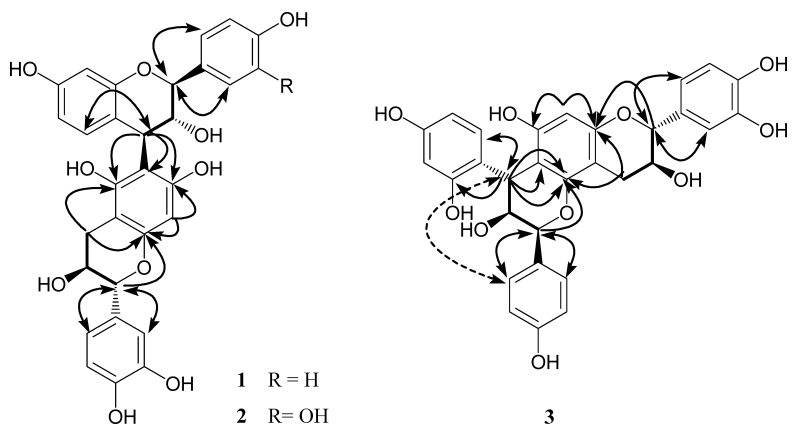

Fig. 2. The Main Correlations of COSY $(\mathrm{H}-\mathrm{H})$, HMBC $(\mathrm{H} \rightarrow \mathrm{C})$ and NOESY $(\mathrm{H} \rightarrow \mathrm{H})$ Correlations for Compounds 1, 2 and $\mathbf{3}$ bearing aromatic carbon) indicate that the signals at $\delta_{\mathrm{C}}$ $106.7, \delta_{\mathrm{C}} 155.6$ and $\delta_{\mathrm{H}} 5.90$ should be assigned as C-6", C-9" and $\mathrm{H}-8^{\prime \prime}$, respectively, and also prove the existence of a $4 \rightarrow 6$ " interflavanoid linkage (Fig. 2).

Thus, the putative structure of $\mathbf{1}$ was similar to that of guibourtinidol- $(4 \alpha \rightarrow 6)$-catechin, which has already been reported. $^{9)}$ It showed negative Cotton effect at $200-220 \mathrm{~nm}$ in the circular dichroism (CD) spectrum defined an $\alpha$ orientation at $\mathrm{C}-4$, that is, the $4 S$ configuration. ${ }^{9)}$ However, 1 showed a high-amplitude positive Cotton effect at $215 \mathrm{~nm}$ in the CD spectrum defined as a $\beta$ orientation at $\mathrm{C}-4$, that is, the $4 R$ configuration. ${ }^{9)}$ In addition, the absolute configurations of $2 S, 3 R$ were determined based on the large coupling constant of the C-ring. Thus, the above results indicated that compound 1 was ent-guibourtinidol- $(4 \beta \rightarrow 6)$-catechin.

Compound 2 was obtained as an amorphous red-brown powder. Aspects of its TLC, FT-IR, and NMR spectra were similar to those of compound 1. HR-negative FAB-MS $(\mathrm{m} / \mathrm{z}$ 561.1401 [M-H] $]^{-}$, Calcd for $\mathrm{C}_{30} \mathrm{H}_{25} \mathrm{O}_{11}, 561.1397$ ) revealed a molecular formula of $\mathrm{C}_{30} \mathrm{H}_{26} \mathrm{O}_{11}$, which indicated the presence of one more oxygen than in compound 1 . The ${ }^{1} \mathrm{H}-\mathrm{NMR}$ spectrum of $\mathbf{2}$ showed three sets of ABX-typed aromatic rings, indicating that the proanthocyanidin contained fisetinidol and catechin moieties compared with 1 (Fig. 2, Table 1). Furthermore, with the exception of an ABX-typed aromatic ring instead of an $\mathrm{A}_{2} \mathrm{~B}_{2}$-spin system, the 1D/2D NMR spectrum of $\mathbf{2}$ was almost identical to that of $\mathbf{1}$.

Based on the above, the structure of $\mathbf{2}$ appeared to be

Table 1. ${ }^{1} \mathrm{H}$ - and ${ }^{13} \mathrm{C}-\mathrm{NMR}$ Data of $\mathbf{1}$ and $\mathbf{2}$ (in DMSO- $d_{6}+\mathrm{D}_{2} \mathrm{O}$ )

\begin{tabular}{|c|c|c|c|c|c|}
\hline \multicolumn{2}{|c|}{ Positions } & \multicolumn{2}{|c|}{1} & \multicolumn{2}{|c|}{2} \\
\hline & & $\delta_{\mathrm{H}}(\mathrm{mult}, J, \mathrm{~Hz})^{a)}$ & $\delta_{\mathrm{C}}{ }^{b)}$ & $\delta_{\mathrm{H}}(\text { mult }, J, \mathrm{~Hz})^{a)}$ & $\delta_{\mathrm{C}}{ }^{b)}$ \\
\hline \multirow{9}{*}{ A and $C$ Rings } & 2 & $4.44(\mathrm{~d}, 9.3)$ & 83.1 & $4.36(\mathrm{~d}, 9.6)$ & 83.4 \\
\hline & 3 & $4.48(\mathrm{t}, 9.3)$ & 68.2 & $4.46(t, 9.6)$ & 68.2 \\
\hline & $4_{\mathrm{eq}}$ & $4.34(\mathrm{~d}, 9.3)$ & 40.7 & $4.32(\mathrm{~d}, 9.6)$ & 40.7 \\
\hline & 5 & $6.48(\mathrm{~d}, 9.0)$ & 128.9 & $6.48(\mathrm{~d}, 8.4)$ & 128.9 \\
\hline & 6 & $6.17(\mathrm{dd}, 2.4,9.0)$ & 108.5 & $6.17(\mathrm{dd}, 2.4,8.4)$ & 108.5 \\
\hline & 7 & & 155.4 & & 155.3 \\
\hline & 8 & $6.07(\mathrm{~d}, 2.4)$ & 102.3 & $6.07(\mathrm{~d}, 2.4)$ & 102.3 \\
\hline & 9 & & 155.8 & & 155.9 \\
\hline & 10 & & 118.5 & & 118.5 \\
\hline \multirow[t]{6}{*}{$\mathrm{B}$ ring } & $1^{\prime}$ & & 130.7 & & 131.4 \\
\hline & $2^{\prime}$ & $7.17(\mathrm{~d}, 8.4)$ & 129.6 & $6.79(\mathrm{~d}, 1.8)$ & 115.6 \\
\hline & $3^{\prime}$ & $6.72(\mathrm{~d}, 8.4)$ & 115.0 & & $145.0-145.2$ \\
\hline & $4^{\prime}$ & & 157.1 & & \\
\hline & $5^{\prime}$ & $6.72(\mathrm{~d}, 8.4)$ & 115.0 & $6.68(\mathrm{~d}, 7.8)$ & 115.4 \\
\hline & $6^{\prime}$ & $7.17(\mathrm{~d}, 8.4)$ & 129.6 & $6.64(\mathrm{~m})$ & 120.0 \\
\hline \multirow[t]{10}{*}{$\mathrm{D}$ and $\mathrm{F}$ rings } & $2^{\prime \prime}$ & $4.51(\mathrm{~d}, 7.8)$ & 81.6 & $4.51(\mathrm{~d}, 7.8)$ & 81.6 \\
\hline & $3^{\prime \prime}$ & $3.77(\mathrm{ddd}, 5.4,7.8,8.4)$ & 67.1 & $3.78(\mathrm{~m})$ & 67.2 \\
\hline & $4_{\mathrm{ax}}{ }^{\prime \prime}$ & $2.41(\mathrm{dd}, 8.4,15.9)$ & 28.9 & $2.42(\mathrm{dd}, 8.4,15.9)$ & 28.9 \\
\hline & $4_{\mathrm{eq}}{ }^{\prime \prime}$ & $2.80(\mathrm{dd}, 5.4,15.9)$ & & $2.81(\mathrm{dd}, 5.1,15.9)$ & \\
\hline & $5^{\prime \prime}$ & & 154.5 & & 155.0 \\
\hline & $6^{\prime \prime}$ & & 106.7 & & 106.8 \\
\hline & $7^{\prime \prime}$ & & 154.1 & & 154.2 \\
\hline & $8^{\prime \prime}$ & $5.90(\mathrm{~s})$ & 96.1 & $5.91(\mathrm{~s})$ & 96.2 \\
\hline & $9^{\prime \prime}$ & & 155.6 & & 155.4 \\
\hline & $10^{\prime \prime}$ & & 99.8 & & 99.0 \\
\hline \multirow{6}{*}{ E ring } & $1^{\prime \prime \prime}$ & & 130.9 & & 131.6 \\
\hline & $2^{\prime \prime \prime}$ & $6.75(\mathrm{~d}, 1.8)$ & 114.9 & $6.76(\mathrm{~d}, 1.8)$ & 115.0 \\
\hline & $3^{\prime \prime \prime}$ & & 144.6 & & $145.0-145.2$ \\
\hline & $4^{\prime \prime \prime}$ & & 145.0 & & \\
\hline & $5^{\prime \prime \prime}$ & $6.67(\mathrm{~d}, 8.4)$ & 115.3 & $6.68(\mathrm{~d}, 8.4)$ & 115.2 \\
\hline & $6^{\prime \prime \prime}$ & $6.63(\mathrm{dd}, 1.8,8.4)$ & 118.8 & $6.64(\mathrm{brd}, 8.4)$ & 118.8 \\
\hline
\end{tabular}


closely related to that of fisetinidol- $(4 \alpha \rightarrow 6)$-catechin, which has already been reported. ${ }^{10)}$ It showed negative Cotton effect at $200-220 \mathrm{~nm}$ in the CD spectrum defined as an $\alpha$ orientation at $\mathrm{C}-4$, that is, the $4 S$ configuration. However, the $\mathrm{CD}$ spectrum of compound $\mathbf{2}$ showed a strong positive Cotton effect at $216 \mathrm{~nm}$, which defined a $4 \beta$ orientation. ${ }^{9)}$ The large coupling constant of the $\mathrm{C}$-ring and the $\mathrm{CD}$ spectrum indicated an absolute stereochemistry of $2 S, 3 R, 4 R$. Hence, the structure of compound $\mathbf{2}$ was determined as ent-fisetinidol$(4 \beta \rightarrow 6)$-catechin.

Compound $\mathbf{3}$ was obtained as an off-white powder and its TLC, FT-IR, and NMR characteristics were similar to those of compound 1. HR-negative FAB-MS ( $\mathrm{m} / \mathrm{z} \quad 545.1450$ $[\mathrm{M}-\mathrm{H}]^{-}$, Calcd for $\left.\mathrm{C}_{30} \mathrm{H}_{25} \mathrm{O}_{10}, 545.1448\right)$ indicated a molecular formula of $\mathrm{C}_{30} \mathrm{H}_{26} \mathrm{O}_{10}$, which was identical to that of compound 1.

${ }^{1} \mathrm{H}-\mathrm{NMR}$ spectrum of $\mathbf{3}$ provided an aromatic ABX-spin system $\left[\delta_{\mathrm{H}} 6.30\left(1 \mathrm{H}, \mathrm{d}, J=8.4 \mathrm{~Hz}, \mathrm{H}-6^{\prime}\right), 6.13(1 \mathrm{H}, \mathrm{br} \mathrm{d}, J=\right.$ $\left.8.4 \mathrm{~Hz}, \mathrm{H}-5^{\prime}\right)$ and $6.31(1 \mathrm{H}$, br s, H-3') in the A-ring, an aromatic $\mathrm{A}_{2} \mathrm{~B}_{2}$-spin system $\left[\delta_{\mathrm{H}} 7.00\left(2 \mathrm{H}, \mathrm{d}, J=8.4 \mathrm{~Hz}, \mathrm{H}-2^{\prime \prime}, 6^{\prime \prime}\right)\right.$, $\left.6.50\left(2 \mathrm{H}, \mathrm{d}, J=8.4 \mathrm{~Hz}, \mathrm{H}-3^{\prime \prime}, 5^{\prime \prime}\right)\right]$ in the B-ring and three methines $\left[\delta_{\mathrm{H}} 5.24(1 \mathrm{H}\right.$, br s, H-6), $4.41(1 \mathrm{H}, \mathrm{d}, J=2.7 \mathrm{~Hz}, \mathrm{H}-8)$ and $4.38(1 \mathrm{H}$, brd, $J=2.7 \mathrm{~Hz}, \mathrm{H}-7)]$ in the C-ring. HMBC showed correlation peaks between the A, B and C-rings (Fig. 2 , Table 2$)$. The small coupling constants $\left(J_{6,7}<1.0, J_{7,8}=\right.$ $2.7 \mathrm{~Hz}$ ) of these three methines indicated a cis-trans configuration of the heterocyclic $\mathrm{C}$-ring, and these findings suggested an epiguibourtinidol moiety. ${ }^{11)}$ In addition, ${ }^{1} \mathrm{H}-\mathrm{NMR}$ spectrum of $\mathbf{3}$ also showed the other ABX-type aromatic system $\left[\delta_{\mathrm{H}} 6.68\left(1 \mathrm{H}, \mathrm{d}, J=8.4 \mathrm{~Hz}, \mathrm{H}-5^{\prime \prime \prime}\right), 6.60\left(1 \mathrm{H}\right.\right.$, br s, H-2 $\left.2^{\prime \prime \prime}\right)$ and $6.33\left(1 \mathrm{H}\right.$, br d, $\left.\left.J=8.4 \mathrm{~Hz}, \mathrm{H}-6^{\prime \prime \prime}\right)\right]$ in the E-ring, an additional aromatic proton in the D-ring $\left(\delta_{\mathrm{H}} 5.90,1 \mathrm{H}, \mathrm{s}\right)$, and an aliphatic group (a methylene and two methines) $\left[\delta_{\mathrm{H}} 4.40\right.$ $(1 \mathrm{H}, \mathrm{d}, J=7.8 \mathrm{~Hz}, \mathrm{H}-2), 3.70(1 \mathrm{H}, \mathrm{m}, \mathrm{H}-3), 2.65$ (1H, m, H$\left.4_{\text {eq }}\right)$ and $\left.2.41\left(1 \mathrm{H}, \mathrm{dd}, J=7.2,15.6 \mathrm{~Hz}, \mathrm{H}-4_{\mathrm{ax}}\right)\right]$ in the F-ring. $\mathrm{HMBC}$ provided the nature of the connection between the $\mathrm{D}$, $\mathrm{E}$ and F-rings (Fig. 2, Table 2). The large coupling constants between $\mathrm{H}-2$ and $3\left(J_{2,3}=7.8 \mathrm{~Hz}\right)$ indicated a trans configuration, and these findings suggested the presence of a catechin moiety.

In particular, the signals indicating a rotational conformer of 3 were not observed on NMR spectrum even though its configuration was similar to that of compound $\mathbf{1}$, and this finding suggested that compound $\mathbf{3}$ was a phlobatannin related to $\mathbf{1}^{12}$ ) Interestingly, the carbon signal (C-8) corresponding with $\mathrm{C}-4$, which was the linking point in the upper unit of compound 1 , was observed up-field $\left(\delta_{\mathrm{C}} 31.2\right)$ of that observed in compound $1\left(\delta_{\mathrm{C}} 40.7\right)$ in the ${ }^{13} \mathrm{C}$-NMR spectrum of 3 (Table 2). Moreover, HMBC revealed characteristic cross-peaks between the additional aromatic proton in the Dring at $\delta_{\mathrm{H}} 5.90, \delta_{\mathrm{H}} 4.40(\mathrm{H}-2$ which was confirmed by COSY) and $\delta_{\mathrm{C}} 155.2$ (the oxygen-bearing carbon signal), as well as between one of the methine protons of the C-ring $\left(\delta_{\mathrm{H}}\right.$ $5.24, \mathrm{H}-6)$, the methylene protons of the F-ring $\left(\delta_{\mathrm{H}} 2.41\right.$, $2.65, \mathrm{H}-4$ ) and $\delta_{\mathrm{C}} 153.9$ (another oxygen bearing carbon signal). Thus, these correlations proved the existence of tetrahydropyrano[2,3- $f$ chromene and the signals at $\delta_{\mathrm{C}} 155.2, \delta_{\mathrm{C}}$ 153.9 and $\delta_{\mathrm{H}} 5.90$ were assigned as $\mathrm{C}-11, \mathrm{C}-13$ and H-10, respectively (Fig. 2).

In addition, the negative Cotton effect at $210 \mathrm{~nm}$ in its CD spectrum indicated an $8 \alpha$ linkage and a cis-trans configured
Table 2. ${ }^{1} \mathrm{H}$ - and ${ }^{13} \mathrm{C}-\mathrm{NMR}$ Data of $\mathbf{3}$ (in DMSO- $d_{6}+\mathrm{D}_{2} \mathrm{O}$ )

\begin{tabular}{|c|c|c|c|}
\hline \multirow{2}{*}{\multicolumn{2}{|c|}{ Positions }} & \multicolumn{2}{|c|}{3} \\
\hline & & \multirow{2}{*}{$\begin{array}{c}\delta_{\mathrm{H}}(\mathrm{mult}, J, \mathrm{~Hz})^{a)} \\
4.40(\mathrm{~d}, 7.8)\end{array}$} & \multirow{2}{*}{$\begin{array}{l}\delta_{\mathrm{C}}^{b)} \\
81.0\end{array}$} \\
\hline C, D, F-Ring & 2 & & \\
\hline & 3 & $3.70(\mathrm{~m})$ & 66.7 \\
\hline & $4_{\mathrm{ax}}$ & $2.41(\mathrm{dd}, 7.2,15.6)$ & 28.2 \\
\hline & $4_{\text {eq }}^{\mathrm{a} x}$ & $2.65(\mathrm{~m})$ & \\
\hline & 6 & $5.24(\mathrm{br} \mathrm{s})$ & 79.9 \\
\hline & 7 & $4.38(\mathrm{brd}, 2.7)$ & 70.4 \\
\hline & 8 & $4.41(\mathrm{~d}, 2.7)$ & 31.2 \\
\hline & 9 & & 155.4 \\
\hline & 10 & $5.90(\mathrm{~s})$ & 97.2 \\
\hline & 11 & & 155.2 \\
\hline & 12 & & 99.8 \\
\hline & 13 & & 153.9 \\
\hline & 14 & & 104.6 \\
\hline \multirow{6}{*}{ A-ring } & $1^{\prime}$ & & 113.3 \\
\hline & $2^{\prime}$ & & 155.6 \\
\hline & $3^{\prime}$ & $6.31(\mathrm{brs})$ & 102.7 \\
\hline & $4^{\prime}$ & & 154.0 \\
\hline & $5^{\prime}$ & $6.13(\mathrm{brd}, 8.4)$ & 108.2 \\
\hline & $6^{\prime}$ & $6.30(\mathrm{~d}, 8.4)$ & 129.0 \\
\hline \multirow[t]{6}{*}{ B-ring } & $1^{\prime \prime}$ & & 130.3 \\
\hline & $2^{\prime \prime}$ & $7.00(\mathrm{~d}, 8.4)$ & 126.5 \\
\hline & $3^{\prime \prime}$ & $6.50(\mathrm{~d}, 8.4)$ & 115.6 \\
\hline & $4^{\prime \prime}$ & & 156.7 \\
\hline & $5^{\prime \prime}$ & $6.50(\mathrm{~d}, 8.4)$ & 115.6 \\
\hline & $6^{\prime \prime}$ & $7.00(\mathrm{~d}, 8.4)$ & 126.5 \\
\hline \multirow[t]{6}{*}{ E-ring } & $1^{\prime \prime \prime}$ & & 130.8 \\
\hline & $2^{\prime \prime \prime}$ & $6.60($ br s) & 114.5 \\
\hline & $3^{\prime \prime \prime}$ & & 144.8 \\
\hline & $4^{\prime \prime \prime}$ & & 144.8 \\
\hline & $5^{\prime \prime \prime}$ & $6.68(\mathrm{~d}, 8.4)$ & 115.6 \\
\hline & $6^{\prime \prime \prime}$ & $6.33($ br d, 8.4) & 117.7 \\
\hline
\end{tabular}

a) Recorded at $600 \mathrm{MHz}$. b) Recorded at $150 \mathrm{MHz}$.

Table 3. DPPH Radical Scavenging Activities and NO Production Inhibition by Compounds $1-7$

\begin{tabular}{ccc}
\hline \hline Compounds & $\begin{array}{c}\text { DPPH radical } \\
\text { scavenging activity }(\mu \mathrm{M})\end{array}$ & $\begin{array}{c}\text { Inhibitory activity } \\
\text { on NO production }(\mu \mathrm{M})\end{array}$ \\
\hline $\mathbf{1}$ & $25.76 \pm 0.39^{\mathrm{d}}$ & $26.67 \pm 6.92^{\mathrm{b}}$ \\
$\mathbf{2}$ & $13.45 \pm 0.17^{\mathrm{a}}$ & $23.43 \pm 2.57^{\mathrm{b}}$ \\
$\mathbf{3}$ & $18.39 \pm 0.65^{\mathrm{c}}$ & $25.82 \pm 5.95^{\mathrm{b}}$ \\
$\mathbf{4}$ & $16.07 \pm 0.32^{\mathrm{b}}$ & $23.36 \pm 1.20^{\mathrm{b}}$ \\
$\mathbf{5}$ & $33.31 \pm 0.56^{\mathrm{b}}$ & $33.72 \pm 2.08^{\mathrm{b}}$ \\
$\mathbf{6}$ & $16.12 \pm 0.51^{\mathrm{b}}$ & $26.50 \pm 5.39^{\mathrm{b}}$ \\
$\mathbf{7}$ & $13.76 \pm 0.06^{\mathrm{a}}$ & $23.39 \pm 0.74^{\mathrm{b}}$ \\
Vit. C & $13.30 \pm 0.31^{\mathrm{a}}$ & - \\
L-NMMA & - & $7.83 \pm 1.07^{\mathrm{a}}$ \\
\hline
\end{tabular}

Values represent means \pm S.D. of three determinations. Values bearing different superscripts in same columns are significantly different $(p<0.05)$

heterocyclic C-ring, which indicated an absolute stereochemistry of $6 S, 7 S, 8 R .^{12)}$ Furthermore, an association between $\mathrm{H}-2^{\prime \prime}, 6^{\prime \prime}$ in the B-ring and $\mathrm{H}-8$ in the C-ring by nuclear Overhauser effect spectroscopy (NOESY) indicated that the C-ring had a 'sofa conformation' and supported the above absolute stereochemistry. ${ }^{13)}$ Accordingly, compound 3 was identified as $(6 S, 7 S, 8 R)-2-(3,4-d i h y d r o x y p h e n y)-6-(4-$ hydroxyphenyl)-8-(2,4-dihydroxyphenyl)-2,3-trans-6,7-cis7,8-trans-3,4,7,8-tetrahydro-2H,6H-pyrano[2,3-f]chromene3,7,9-triol. The phlobatannins composed of guibourtinidol and catechin moieties have already been reported as 8,9- 
trans-9,10-cis-tetrahydropyrano[2,3-h]chromene, which had $10 \alpha$ (negative Cotton effect at $210 \mathrm{~nm}$ in its CD) or $10 \beta$ (positive Cotton effect at $210 \mathrm{~nm}$ in its CD) linkage. However, the structural and regional isomer, $\mathbf{3}$, is reported here for the first time. ${ }^{14)}$

The naturally occurring phlobatannins are known to be made from 5-dehydroxy-type condensed tannins such as proguibourtinidin and profisetinidin via quinone-methide intermediate. Based on the biomimetic synthesis under mild basic conditions, recyclization involving 5 "- $\mathrm{OH}$ (in the $\mathrm{D}$ ring) and $\mathrm{C}-2$ (in the $\mathrm{C}$-ring) requires rotation of the $\mathrm{C}(3)$ $\mathrm{C}(4)$ bond, which will invariably convert the 3,4-trans to the 3,4-cis configuration. ${ }^{12}$ ) Thus, 3 might have been a metabolic product of proguibourtinidin (guibourtinidol-catechin) such as $\mathbf{1}$ on the root of RM in our present study. Furthermore, this result indicated the existence of an enzyme that could recognize unique 5-dehydroxy-type condensed tannins and produce distinct phlobatannins on the root of RM.

These new stereoisomers of the condensed tannins $(\mathbf{1}-\mathbf{3})$, along with the four known phenolic compounds isolated from the root of RM, were evaluated for 1,1-diphenyl2-picrylhydrazyl (DPPH) radical scavenging activity and inhibitory activity on nitric oxide (NO) production in order to determine their anti-oxidative and anti-inflammatory activity. Among the 5-dehydroxy-condensed tannins, $2\left(\mathrm{IC}_{50}=\right.$ $13.45 \pm 0.17 \mu \mathrm{M})$ was superior to $1\left(\mathrm{IC}_{50}=25.76 \pm 0.39 \mu \mathrm{M}\right)$ significantly $(p<0.05)$ because of the 3,4-dihydroxybenzene B-ring, which plays a very important role in radical scavenging activity. ${ }^{15-16)}$ Due to the additional separate A-ring that possessed a hydroxyl group, $3\left(\mathrm{IC}_{50}=18.39 \pm 0.65 \mu \mathrm{M}\right)$, which was a metabolic product of $\mathbf{1}$, showed more potent free radical scavenging activity than 1 significantly $(p<0.05)$. Among known condensed tannins, the dimer of flavan-3-ol, $7\left(\mathrm{IC}_{50}=\right.$ $13.76 \pm 0.06 \mu \mathrm{M})$ was superior to the monomers $(\mathbf{5}, \mathbf{6})$, and $\mathbf{6}$ $\left(\mathrm{IC}_{50}=16.12 \pm 0.51 \mu \mathrm{M}\right)$ exhibited more potent free radical scavenging activity than $5\left(\mathrm{IC}_{50}=33.31 \pm 0.56 \mu \mathrm{M}\right)$ significantly $(p<0.05)$ (Table 3$)$. These findings indicated that the free radical scavenging activities of condensed tannins were dependent on the number of phenolic hydroxyl groups. In addition, all compounds that did not exhibit toxicity at $100 \mu \mathrm{g} /$ $\mathrm{ml}$ or below on 3-(4,5-dimethylthiazol-2-yl)-2,5-diphenyltetrazolium bromide (MTT) assay (data not shown) moderately inhibited NO production. Free radicals such as peroxynitrite $\left(\mathrm{ONOO}^{-}\right)$produced from $\mathrm{NO}$ are known to play a key role in enhancing inflammation through the activation of nuclear factor (NF)-kappa B and activator protein 1 (AP)-1 transcription factors, development of cyclooxygenase-2 (COX-2), and expression of inducible nitric oxide synthase (iNOS) in various inflammatory diseases. ${ }^{17)}$ Thus, these results suggest that the condensed tannins isolated from the root of RM might be developed as anti-oxidative and anti-inflammatory agents.

\section{Experimental}

General Experimental Methods Sephadex LH-20 $(10-25 \mu \mathrm{m}$, GE Healthcare Bio-Science AB, Uppsala, Sweden) and MCI-gel CHP 20P (75-150 $\mu \mathrm{m}$, Mitsubishi Chemical, Tokyo, Japan) and were used for column chromatography. Reversed-phase MPLC using Water 650E HPLC system equipped with a Gilson 110UV/VIS detector was carried out on ODS columns (Ultra Pack ODS-SM-50B, $300 \times 26 \mathrm{~mm}$ i.d., $50 \mu \mathrm{m}$, Yamazen, Osaka, Japan) with the $\mathrm{MeOH} / \mathrm{H}_{2} \mathrm{O}$ solvent system. TLC was carried out on pre-coated silica gel $60 \mathrm{~F}_{254}$ plate (Merck, Darmstadt, Germany) and spots were detected under $\mathrm{UV}$ radiation $(254 \mathrm{~nm})$ and by spraying with $\mathrm{FeCl}_{3}$ solution and $10 \% \mathrm{H}_{2} \mathrm{SO}_{4}$ or anisaldehyde- $\mathrm{H}_{2} \mathrm{SO}_{4}$ solution followed by heating.
NMR spectra were recorded on a Varian VNS $\left({ }^{1} \mathrm{H}-\mathrm{NMR}, 600 \mathrm{MHz} ;{ }^{13} \mathrm{C}\right.$ NMR, $150 \mathrm{MHz}$ ) instrument. FT-IR spectra were obtained using Magna 750. HR-FAB-MS was measured with JMS-AX505WA. Optical rotations and circular dichroism spectra were measured on Autopol III polarimeter and J-715 spectropolarimeter, respectively.

Plant Material The roots of RM, which had already been cut, were purchased on Gyeongdong Market (Seoul, Korea) in March 2008 and the identity of this plant material was confirmed by TLC by comparison with another root of RM (Yesan, Korea), certified by Prof. Lee (Pharmacognosy Lab, College of Pharmacy, Chung-Ang University). The voucher specimen (RMR2008) was deposited at the herbarium of the College of Pharmacy, Chung-Ang University.

Extraction and Isolation Two kilograms of the roots of RM were extracted several times with $80 \%$ acetone at room temperature. After removing the acetone under vacuum, the residual aqueous solution was filtered. The filtrate was then concentrated (160 g), applied to Sephadex LH-20 (2 kg, $10 \times 80 \mathrm{~cm}$ ) and eluted with water containing increasing proportions of $\mathrm{MeOH}$ to afford 3 sub-fractions. Sixteen grams of fraction 2 was subjected to MCI-gel CHP20P $(600 \mathrm{~g}, 5 \times 60 \mathrm{~cm})$ with a gradient elution system of water-methanol to yield 4 (42 mg), $5(2500 \mathrm{mg})$ and three additional subfractions. Repeated column chromatography of these sub-fractions using reversed-phase MPLC $\left(300 \times 26 \mathrm{~mm}\right.$ i.d., $50 \mu \mathrm{m}, 0-30 \% \mathrm{MeOH}$ in $\left.\mathrm{H}_{2} \mathrm{O}\right)$ yielded 1 (237 mg), 2 (143 mg), 3 (141 mg), 6 (20 mg) and $7(150 \mathrm{mg})$, respectively

ent-Guibourtinidol- $(4 \beta \rightarrow 6)$-catechin (1): Amorphous red-brown powder. $[\alpha]_{\mathrm{D}}^{25}+100^{\circ}(c=0.0014, \mathrm{MeOH})$. IR $(\mathrm{KBr}) \mathrm{cm}^{-1}: 3350,1600,1475$. HR FAB-MS $m / z$ : $545.1453[\mathrm{M}-\mathrm{H}]^{-}\left(\right.$Calcd for $\left.\mathrm{C}_{30} \mathrm{H}_{25} \mathrm{O}_{10}, 545.1448\right)$. c.d. $[\theta]_{286} 3.15,[\theta]_{283} 0,[\theta]_{274}-6.32,[\theta]_{251} 0,[\theta]_{240} 6.69,[\theta]_{215} 62.07,[\theta]_{200} 0$. ${ }^{1} \mathrm{H}$ - and ${ }^{13} \mathrm{C}$-NMR data: see Table 1 .

ent-Fisetinidol- $(4 \beta \rightarrow 6)$-catechin (2): Amorphous red-brown powder. $[\alpha]_{\mathrm{D}}^{25}+130^{\circ}(\mathrm{c}=0.0015, \mathrm{MeOH})$. IR $(\mathrm{KBr}) \mathrm{cm}^{-1}: 3350,1600,1475$. HRFAB-MS $m / z: 561.1401[\mathrm{M}-\mathrm{H}]^{-}$(Calcd for $\mathrm{C}_{30} \mathrm{H}_{25} \mathrm{O}_{11}, 561.1397$ ). c.d. $[\theta]_{286} 4.59,[\theta]_{282} 0,[\theta]_{273}-7.16,[\theta]_{247} 0,[\theta]_{240} 6.78,[\theta]_{216} 53.27,[\theta]_{210} 0$. ${ }^{1} \mathrm{H}$ - and ${ }^{13} \mathrm{C}$-NMR data: see Table 1 .

(6S,7S,8R)-2-(3,4-Dihydroxyphenyl)-6-(4-hydroxyphenyl)-8-(2,4-dihydroxyphenyl)-2,3-trans-6,7-cis-7,8-trans-3,4,9,10-tetrahydro- $2 \mathrm{H}, 6 \mathrm{H}$ pyrano[2,3-f]chromene-3,7,9-triol (3): Amorphous off-white powder. $[\alpha]_{\mathrm{D}}^{25}$ $-100^{\circ}(\mathrm{c}=0.0014, \mathrm{MeOH})$. IR $(\mathrm{KBr}) \mathrm{cm}^{-1}: 3350,1600,1475$. HR-FABMS $m / z: 545.1450[\mathrm{M}-\mathrm{H}]^{-}$(Calcd for $\left.\mathrm{C}_{30} \mathrm{H}_{25} \mathrm{O}_{10}, 545.1448\right)$. c.d. $[\theta]_{278}$ 5.14, $[\theta]_{250} 0,[\theta]_{236}-20.50,[\theta]_{210}-11.91,[\theta]_{203} 0 .{ }^{1} \mathrm{H}-$ and ${ }^{13} \mathrm{C}-\mathrm{NMR}$ data: see Table 2

Measurement of DPPH Radical Scavenging Activity DPPH (Sigma, St. Louis, MO, U.S.A.) radical scavenging assays were performed in order to evaluate the anti-oxidative activity of each component isolated from the roots of RM. Briefly, $20 \mu$ of each sample in absolute EtOH was added to $180 \mu \mathrm{l}$ of a DPPH solution $(0.1 \mathrm{~mm}$, in absolute EtOH). After mixing gently for $30 \mathrm{~min}$, optical densities were measured at $540 \mathrm{~nm}$ using a microplate reader (TECAN, Salzburg, Austria). L-Ascorbic acid was used as a positive control.

Cell Culture Mouse macrophage RAW 264.7 cells were purchased from the Korean Cell Line Bank. These cells were grown at $37^{\circ} \mathrm{C}$ in a humidified atmosphere $\left(5 \% \mathrm{CO}_{2}\right)$ in Dulbecco's modified Eagle's medium (DMEM) (Sigma, St. Louis, MO, U.S.A.) containing 10\% fetal bovine serum, $100 \mathrm{IU} / \mathrm{ml}$ penicillin $\mathrm{G}$ and $100 \mathrm{mg} / \mathrm{ml}$ streptomycin (Gibco BRL, Grand Island, NY, U.S.A.).

Measurement of Cell Viability Cell viability was measured by the 3(4,5-dimethylthiazol-2-yl)-2,5-diphenyltetra-zoliumbromide (MTT) assay, which is based on the reduction of MTT to formazan by mitochondrial dehydrogenase. Briefly, the cells $\left(3 \times 10^{4} / 200 \mu \mathrm{l}\right.$ medium $)$ were treated with each sample and incubated for $24 \mathrm{~h}$ at $37^{\circ} \mathrm{C}$. After MTT reagent $(0.5 \mathrm{mg} / \mathrm{ml})$ (Sigma, St. Louis, MO, U.S.A.) was added to medium and incubated for an additional $4 \mathrm{~h}$, the medium was then removed and the MTT-formazan was dissolved in $200 \mu$ l dimethylsulfoxide (DMSO). The extent of the reduction of MTT to formazan was quantified by measuring the absorbance at $540 \mathrm{~nm}$ using a microplate reader.

Measurement of Inhibitory Effect on NO Production NO liberated from RAW 264.7 cells was measured by Griess assay. Briefly, RAW 264.7 cells $\left(3 \times 10^{4} / 200 \mu \mathrm{l}\right.$ medium) stimulated by $1 \mu \mathrm{g} / \mathrm{ml}$ lipopolysaccharide (LPS) were treated with each sample and incubated for $24 \mathrm{~h}$ at $37^{\circ} \mathrm{C}$. The medium was then mixed with an equal volume of Griess reagent (Sigma, St. Louis, MO, U.S.A.). The amount of $\mathrm{NO}$ was quantified by measuring the absorbance at $540 \mathrm{~nm}$ using a microplate reader and was determined from a sodium nitrite standard curve.

Statistical Analysis All data are expressed means \pm S.D. Analysis was 
performed by one-way analysis of variance (ANOVA) followed by the Student-Newman-Keuls (S-N-K) test. Results were considered to be significantly different when $p$ values were less than 0.05 . Values bearing different superscripts indicate significant differences.

Acknowledgement This work was supported by Seoul R\& BD program.

\section{References}

1) Fawcett R. S., Weeds Today, 11, 22-23 (1980).

2) Kim C. M., Shin M. K., Ahn D. K., Lee, K. S., "An Unabridged Dictionary of Chinese Herbs," Jeongdam Publishing House, Seoul, 1998, pp. $4735-4738$.

3) Takahashi K., Ogura M., Tanabe Y., Chem. Pharm. Bull., 17, 2223 2229 (1969).

4) Du H. Q., Zhao X., Zhao T. Z., Wang M. T., Zhang Z. W., Yao M., Yu S. Z., Acta Pharmaceut. Sin., 18, 314-316 (1983).

5) Yeo H., Park S. Y., Kim J., Phytochemistry, 48, 1399-1401 (1998).

6) Yeo H., Chin Y. W., Park S. Y., Kim J., Arch. Pharm. Res., 27, 287290 (2004)

7) Lu Y., Yeap Foo L., Food Chemistry, 65, 1—8 (1999).
8) Fan J., Ding X., Gu W., Food Chemistry, 102, 168-177 (2007).

9) Ferreira D., Preez I. C. D., Wijnmaalen J. C., Roux D. G., Phytochemistry, 24, 2415-2422 (1985)

10) Botha, J. J., Ferreira, D., Roux, D. G., J. Chem. Soc., Perkin Trans. 1, 1981, 1235 (1981).

11) Bonnet S. L., Steynberg J. P., Bezuidenhoudt B. C. B., Saunders C. M., Ferreira D., Phytochemistry, 43, 253-263 (1996).

12) Steynberg J. P., Burger J. F. W., Young D. A., Brandt E. V., Steenkamp J. A., Ferreira D., J. Chem. Soc., Perkin Trans. 1, 1988, 3323-3329 (1988).

13) Steenkamp J. A., Steynberg J. P., Brandt E. V., Ferreira D., Roux D. G., J. Chem. Soc., Chem. Commun., 1985, 1678-1679 (1985).

14) Steynberg P. J., Burger J. F. W., Bezuidenhoudt B. C. B., Steynberg J. P., Van Dyk M. S., Ferreira D., Tetrahedron Lett., 31, 2059-2062 (1990).

15) Hirano R., Sasamoto W., Matsumoto A., Itakura H., Igarashi O., Kondo K., J. Nutr. Sci. Vitaminol., 47, 357-362 (2001).

16) Haraguchi H., Ishikawa H., Sanchez Y., Ogura T., Kubo Y., Kubo I., Bioorg. Med. Chem., 5, 865-871 (1997).

17) Ivanov V., Merkenschlager M., Ceredig R., J. Immunol., 151, 46944704 (1993). 